Conf- $950646--14$

UCRL-JC-119716

PREPRINT

\title{
Variability in the Intraspecific Response of Pinus Ponderosa Seedlings Subjected to Long-Term Exposure to Elevated $\mathrm{CO}_{2}$
}

\author{
James L.J. Houpis \\ James C. Pushnik \\ David J. Anschel \\ Paul D. Anderson
}

This paper was prepared for submittal to the 88th Annual Meeting \& Exhibition

Air \& Waste Management

San Antonio, Texas

June 18-23, 1995

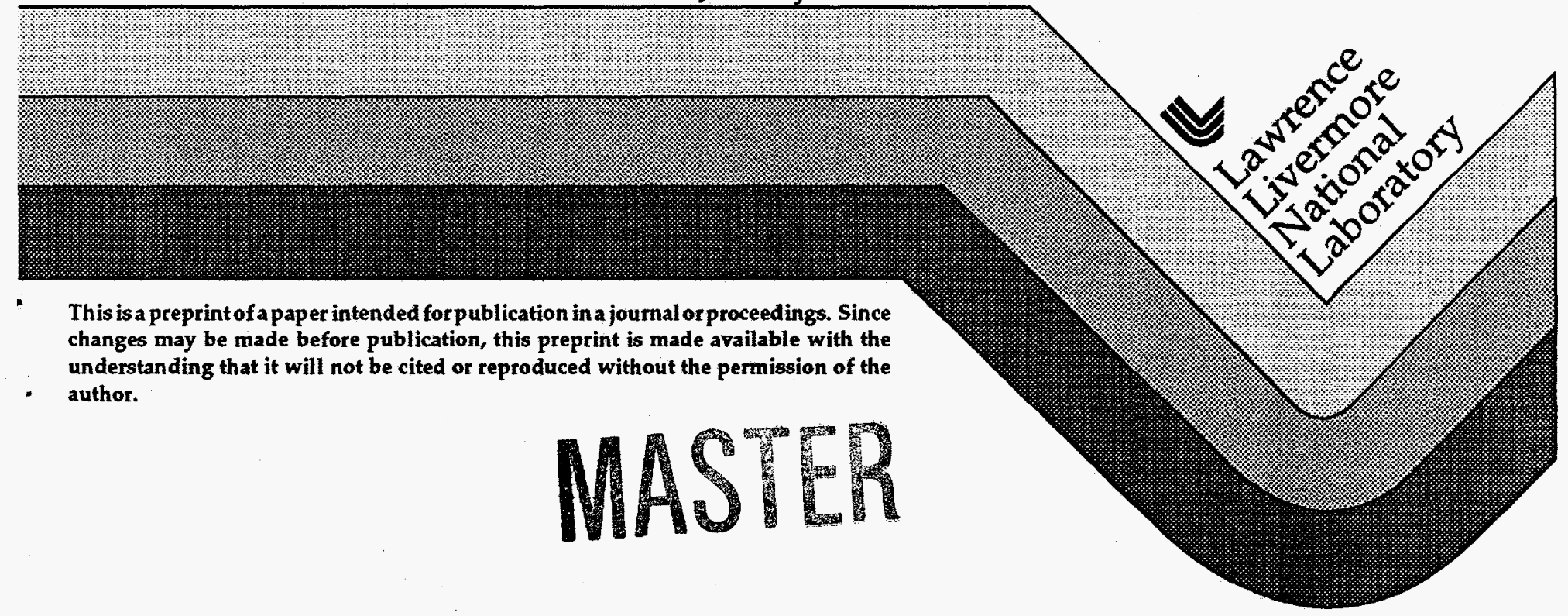




\section{DISCLAIMER}

This report was prepared as an account of work sponsored by an agency of the United States Government. Neither the United States Government nor any agency thereof, nor any of their employees, makes any warranty, express or implied, or assumes any legal liability or responsibility for the accuracy, completeness, or usefulness of any information, apparatus, product, or process disclosed, or represents that its use would not infringe privately owned rights. Reference herein to any specific commercial product, process, or service by trade name, trademark, manufacturer, or otherwise does not necessarily constitute or imply its endorsement, recommendation, or favoring by the United States Government or any agency thereof. The views and opinions of authors expressed herein do not necessarily state or reflect those of the United States Government or any agency thereof. 


\section{DISCLAIMER}

Portions of this document may be illegible in electronic image products. Images are produced from the best available original document. 
Variability in the Intraspecific Response of Pinus ponderosa Seedlings Subjected to Long-Term Exposure to Elevated $\mathrm{CO}_{2}$

\author{
James L.J. Houpis \\ Health and Ecological Assessment Division \\ Lawrence Livermore National Laboratory \\ P.O. Box 808, L-559 \\ Livermore, CA 94551 \\ James C. Pushnik \\ Department of Biological Sciences \\ California State University at Chico \\ Chico, CA 95929 \\ David J. Anschel \\ Health and Ecological Assessment Division \\ Lawrence Livermore National Laboratory \\ P.O. Box 808, L-559 \\ Livermore, CA 94551 \\ Paul D. Anderson \\ U.S. Forest Service \\ P.O. Box 898 \\ 5985 Hwy K \\ Rhinelander, WI 54501
}

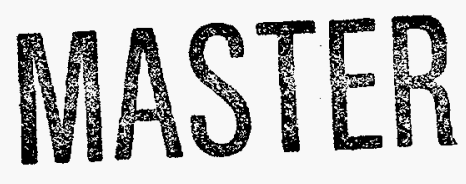




\section{INTRODUCTION}

It has been widely reported that, due largely to the burning of fossil fuels, there has been a gradual increase in atmospheric $\mathrm{CO}_{2}$ which may result in a general increase in the earth's atmospheric temperature. ${ }^{1,2,3}$ Before the industrial revolution, atmospheric $\mathrm{CO}_{2}$ has been estimated at between 260 and $290 \mathrm{ppm}$. By 1980, this level had increased to 335 to $340 \mathrm{ppm}$. It is projected that $\mathrm{CO}_{2}$ levels could double to $600 \mathrm{ppm}$ by the middle of the next century, resulting in changes in Earth's climate which may be sudden rather than gradual. ${ }^{4}$

There is considerable concern, therefore, as to the possible ecological effects of rising atmospheric $\mathrm{CO}_{2}$, increasing mean temperatures, increases or decreases in precipitation patterns, and other related climate changes. The importance of forests and their interaction with climate change is considerable. Forests occupy 22 percent of the earth's land area (excluding the polar region), while accounting for as much as two-thirds of global photosynthesis. This would occur primarily in young, vigorously growing forests that are capable of accumulating biomass. The use of forests as carbon sinks focuses attention on the desirability of establishing vast areas of new plantations and the development of new forest management practices. $^{5,6}$ Also, forests may undergo changes in species composition or distribution due to changes in ambient $\mathrm{CO}_{2}$, temperature, and precipitation ${ }^{7}$, particularly for species or individuals occupying marginal habitats. The extent of these impacts is not well known, and the level of uncertainty in estimating these impacts remains high, even after many years of research on elevated $\mathrm{CO}_{2}$ concentrations.

It is generally acknowledged that elevated levels of atmospheric $\mathrm{CO}_{2}$ increases growth and dry matter production of herbaceous plants experiencing otherwise ideal conditions. ${ }^{8}$ In most cases, growth represents the translocation of recently acquired or stored resources into structural material that is directly involved in support and for the further acquisition and transport of additional resources (eg., foliage, roots and conducting tissues). . This increased growth rate due to elevated $\mathrm{CO}_{2}$ may be attributed to such factors as increased photosynthetic rate, ${ }^{8}$ inhibition of photorespiration, ${ }^{9}$ decreased in stomatal conductance of $\mathrm{CO}_{2}$ and water vapor, ${ }^{10,11}$ increased water use efficiency, ${ }^{12}$ and/or increased foliar area. ${ }^{13}$

While a majority of studies investigating the effect of elevated $\mathrm{CO}_{2}$ involved annular species, such as agricultural or floral crop plants, only a relatively few studies have researched longer lived species. Furthermore, there has been only a minimal number of studies that were conducted for one year or longer. ${ }^{14,15,16,17,18}$ Experimental exposure of tree species to elevated atmospheric $\mathrm{CO}_{2}$ has revealed a diverse range of responses. A general trend has been reported of increased carbon assimilation that leads to increased growth of young trees. The growth enhancement results from physiological adaptations which optimize photosynthetic carbon acquisition and allocation processes. ${ }^{19,9}$ In general, growth is expressed as increased biomass partitioned between different plant structures (e.g. foliage, stems and roots) and results in particular shifts in root/shoot ratios. These growth responses vary widely between genera, species within the same genera ${ }^{12}$ and intraspecifically. ${ }^{20}$ A review of the literature, also indicated that observed increases in photosynthetic rates averaged near $40 \%$ for coniferous tree species and near $60 \%$ for deciduous tree species. ${ }^{21}$ Various forms of regulation of assimilation were reported, consisting of stomatal (physiological) and non-stomatal (metabolic) limitations, ${ }^{22}$ both of which can be influenced by $\mathrm{CO}_{2}$ concentrations. Collectively these observational differences suggest that multiple factors may be operating in concert to determine the extent of growth enhancement due to elevated atmospheric $\mathrm{CO}_{2}$ concentrations. 
In addition to intra- and interspecific differences, analysis of the effects of elevated $\mathrm{CO}_{2}$ is complicating by the length of study. Numerous investigations examining the long-term effects of elevated $\mathrm{CO}_{2}$ levels on growth, have revealed an initial increase in carbon assimilation followed by a reduction in carbon assimilation and growth (i.e. acclimation to elevated $\mathrm{CO}_{2}$ ). ${ }^{23,24,25,26}$ Several studies have indicated that photosynthetic acclimation to elevated $\mathrm{CO}_{2}$ may occur in several species. As described by Samuelson and Seiler $^{27}$ for Picea rubens, photosynthetic rates following two years of exposure to ambient or twice ambient $\mathrm{CO}_{2}$, the elevated $\mathrm{CO}_{2}$ exposed plants exhibited higher assimilation rates than ambient grown plants when measured at their respective growth concentrations. However, when both ambient and elevated $\mathrm{CO}_{2}$ grown plants were measured for photosynthetic rates at the same $\mathrm{CO}_{2}$ concentration, either ambient or twice ambient leveis, the ambient grown seedlings exhibited higher assimilation rates. Photosynthetic acclimation is most likely the result of mesophyll limitations ${ }^{27}$ associated with alterations in source:sink relations. ${ }^{21}$ In the absence of active sinks, carbon assimilation may be restricted by feedback inhibitions and reductions of RuBCase amount or activity. In some cases, photosynthetic acclimation may have been artifacts of restrictions placed on root-sink strength imposed by small pot volumes, ${ }^{28}$ but other cases of acclimation have been documented for plants with unrestricted rooting volumes.

Collectively, these studies suggest that intermediate physiological and biochemical mechanisms might be functioning as regulatory processes which feedback to whole plant physiological activity. The principle physiological and biochemical mechanisms which have been individually suggested as feedback regulators resulting in acclimation are: 1) decreased stomatal conductance by elevated internal $\mathrm{CO}_{2}$ concentrations $\left(\mathrm{C}_{\mathbf{i}}\right)$; 2) mesophyll limitations; i.e. changes in the photosystem, decreases in the activity or levels of ribulose-1,5-bisphosphate carboxylase (RuBPCase); and 3) the accumulation of high concentrations of starch within the chloroplast, possibly associated with a reduction in sucrose-phosphate-synthase (SPS) resulting in disruption of thylakoid structure. However, none of these mechanisms individually account for observed data, and consequently can not be viewed as the controlling mechanism. Since all of these processes are biochemically linked through metabolism, each component acting in turn as a sink then as a source for subsequent processes, it seems quite reasonable to examine the relative activities of selected carbon sources, as they correlate with intermediate (carbon allocation patterns) and long-term carbon sinks (plant growth).

The following mechanistic control framework emerges as a coordinating process for carbon accumulation which is regulated but not overall limited by a series of self integrating source/sink feedback loops. In concept, this coordinating process is subdivided into control points: 1) stomatal and non-stomatal limitations to carbon assimilation; 2) changes in activity levels of carboxylation, starch synthesis and sucrose synthesis; and 3) carbon allocation to biomass and carbohydrate storage.

The first control point encompasses the increase in $\mathrm{C}_{\mathrm{i}}$ driven by the steepness of the ambient to internal gradient of $\mathrm{CO}_{2}$ in an elevated $\mathrm{CO}_{2}$ atmosphere. The $\mathrm{C}_{\mathrm{i}}$ concentration is acting as the initial sink and can be feedback regulated by physiological response and carbon allocation patterns by influencing the stomatal aperture and overall stomatal frequency. Stomates physiologically adjust, within limits, to maintain the flux of $\mathrm{CO}_{2}$ into the leaf constant, by sensing the $\mathrm{CO}_{2}$ concentration in or around the guard cells.

The extent of the influence of the $C_{i}$ feedback loop is modulated by properties of the photosystem and the activity level of RuBPCase. The status of the photosystem can be evaluated through examination of chlorophyll fluorescence. It has been shown that changes in chlorophyll fluorescence emission during the induction of photosynthesis are closely related to the rate of $\mathrm{CO}_{2}$ assimilation. ${ }^{29}$ Additionally, 
Lichtenthaler and Rinderle ${ }^{30}$ have written that the reciprocal relationship between in vivo chlorophyll fluorescence and photosynthetic activity can be used to detect stress effects on green plants and to study the potential photosynthetic activity of leaves. The main fluorescence parameter which is typically used is the ratio of the variable fluorescence to the maximal fluorescence ( $\mathrm{Fv} / \mathrm{Fm}$ ), which indicates the relative photochemical efficiency of photosystem II. The transfer of electrons associated with chlorophyll fluorescence measurements use pigment molecules. Krause and Weis ${ }^{31}$ have claimed that fluorescence at Fo (non-variable fluorescence) is an emission by antenna chlorophyll $a$ molecules. So then chlorophyll $a$ levels might directly influence chlorophyll fluorescence. $\mathrm{Fv} / \mathrm{Fm}$ would be influenced since $\mathrm{Fv}$ is a function of Fo. Changes in pigmentation alone have been used as an indication of physiological alterations associated with elevated $\mathrm{CO}_{2}{ }^{32}$

The activity level of RuBPCase which functions as the immediate carbon sink responsible for reducing $\mathrm{C}_{\mathrm{i}}$, the second control point. Factors which regulate this control point include, enzyme activity leveis and chloroplast $\mathrm{CO}_{2}$ concentrations at the site of carboxylation $\left(\mathrm{C}_{\mathrm{c}}\right) . \mathrm{CO}_{2}$ in the internal cellular air spaces must diffuse along a concentration gradient from the substomatal cavity to the chloroplast transversing intervening cellular structures. These cellular structures form a resistance barrier to $\mathrm{CO}_{2}$ diffusion and are collectively referred to as mesophyll conductance $\left(\mathrm{g}_{\mathrm{nss}}\right)$. The extent of the influence of $\mathrm{g}_{\text {nsl }}$ on the diffusional pathway of $\mathrm{CO}_{2}$ is determined by thickness of the mesophyll, porosity, cell sizes and shapes, permeabilities of cell walls, plasmalemma, cytosol, chloroplast envelope and stroma. ${ }^{33}$ The net effect of increasing $\mathrm{g}_{\mathrm{ns}}$ would be to decrease $\mathrm{C}_{\mathrm{c}}$, thereby reducing RuBCase substrate levels. Carboxylation efficiency is regulated by Michaelis-Menten kinetics and enzyme concentration per unit area, as well as sink strengths for the primary photosynthate glyceraldehyde-3-phosphate (G-3-P).

RuBPCase's ultimate reaction product (G-3-P) can be directed to one of two separate sinks dependent upon sink activity. If cytoplasmic demand for triose-phosphates is low or chloroplast export is hindered by low cellular phosphate, newly acquired photoassimilate is directed to starch synthesis within the chloroplast. Alternately, sucrose-phosphate-synthase (SPS) can act as a cytoplasmic metabolic sink for photosynthetic products. SPS activity is differentially feedback regulated by physiological cellular status. Enzyme activity is modulated by protein phosphorylation (indirectly cellular $\mathrm{P}$ content) and by endogenous levels of sucrose. ${ }^{34}$ Maximal levels of SPS activity would be expected during periods of high photoassimilation and actively developing metabolic sinks.

Feedback regulation of SPS activity by cellular sucrose concentrations is dependent upon two separate sink strengths, cellular respiratory demands and development of long-term storage sinks. The relative strengths of these competing processes constitute the third control point, which is phenologically and genetically regulated or by transport limitation of resource allocation to various long-term sinks. These long-term sinks would include increases in the vascular tissue, seasonal storage carbohydrate in the form of root starch, synthesis of secondary plant products and finally into the overall growth.

Our study uses this source/sink control framework at several key integrating steps, incorporating the long-term effects of elevated $\mathrm{CO}_{2}$ (insuring sufficient time for the expression of any long-term physiological and biochemical acclimation to occur) and genetics (using multiple species and multiple known genetic sources) in an attempt to ascertain the extent of overall regulation contributed by selected independent regulatory process at the physiological, biochemical and structural level. In order to assess intraspecific variability, this paper reports on the integration of measurements of photosynthesis, chlorophyll fluorescence, pigmentation, RuBPCase, SPSase to quantify the effects of elevated $\mathrm{CO}_{2}$ on the growth response of various families of the same species. 


\section{Experimental Species}

For our experimentation efforts, we used Pinus ponderosa. $P$. ponderosa is the most ranging and most abundant of the mixed conifers inhabiting broad stretches of North America and Eurasia, it is also widely cultivated in the Southern Hemisphere. It is also a shade intolerant, canopy dominant species. $P$.

ponderosa remains photosynthetically active the entire year, thus making it a important long-term carbon sink on the global scale.

\section{Plant Material and Growth Conditions}

We are investigating the effects of elevated $\mathrm{CO}_{2}$ and intraspecific variability on $P$. ponderosa. To analyze intraspecific variability, we included seedling source (family) as an additional treatment, using a split-plot experimental design. We included nine different families in this experiment for analysis of growth. There were four sets of half siblings families (Family 3087, 3088, 3399, and 3354), obtained from parent populations located at mid-elevation (ca. $1500 \mathrm{~m}$ ) in the central Sierra Nevada of California (El Dorado National Forest). The other five plants were from open-pollinated sources and were obtained from different geographic regions: Mendocino California (OP5), Sierra (eastern) California (OP6), San Bernandino California (OP7), Santa Clara California (OP8) and El Dorado County California (OP9). Of these families, only Families 3087,3088 , and 3399 were used to compare the variability in the physiological and biochemical response to elevated $\mathrm{CO}_{2}$. Seedlings were grown in containers with a volume, $12.8 \mathrm{~L}$, which is large enough that pot restrictions on carbon sink size would not occur during the study period. ${ }^{35,28}$ The potted seedlings were grown in eighteen standard outdoor open-top chambers (a cylindrical shaped outdoor chamber, $3 \mathrm{~m}$ in diameter, and $3 \mathrm{~m}$ in height) at the Lawrence Livermore National Laboratory exposure facility. All seedlings were well-watered and fertilized using a one-half strength Hoagland's solution.

\section{$\mathrm{CO}_{2}$ Treatments}

The three elevated $\mathrm{CO}_{2}$ treatments were ambient (approx. $350 \mathrm{ppm} \mathrm{CO}_{2}$ ), ambient $+175 \mathrm{ppm} \mathrm{CO}_{2}$ and ambient $+350 \mathrm{ppm} \mathrm{CO}$. The concentrations of $\mathrm{CO}_{2}$ in the open-top chambers were monitored using dedicated $\mathrm{CO}_{2}$ analyzers (Horiba Model PIR-2000; all analyzers were zero and span checked daily and under went a complete multipoint calibration every month). Chamber atmospheres were sampled twelve times per hour at canopy height, at the center of the chamber, for approximately one minute, and the measures of $\mathrm{CO}_{2}$ concentration were averaged over the one-minute sampling period. The chamber $\mathrm{CO}_{2}$ concentrations were maintained within $\pm 5 \%$ of the treatment concentration. $\mathrm{CO}_{2}$ treatment concentrations were continuous, $24 \mathrm{hr}$ per day, for the entire length of the study.

\section{Growth Measurements}

Growth measurements consisted of the height and diameter of the main stem. Height measurements were taken to the nearest $0.5 \mathrm{~cm}$ using a tape measure. Diameter was measured at the cotyledon whorl with a vernier caliper to the nearest $0.1 \mathrm{~mm}$.

\section{Photosynthesis Measurements}

Photosynthetic rates were measured using a closed-loop photosynthesis system consisting of a portable infrared gas analyzer and microprocessor controller (model Li-6200, Licor Inc., Lincoln, NB) coupled with a light controlled cuvette. Samples were all measured at a constant light level of $1000 \mu \mathrm{E} \mathrm{m} \mathrm{s}^{-2}$. 


\section{Light Harvesting Measurements}

Estimates of [ci] and the photochemical efficiency of electron transport reactions for photosystem II $\left(\mathrm{F}_{\mathrm{II}}\right)$ were made using chlorophyll fluorescence techniques. ${ }^{36}$ All measurements were made after a minimum of 45 minutes following dark adaptation on in situ samples using a portable Morgan CF-1000 Chlorophyll Fluorescence Measurement System (Morgan Scientific, Andover MA.). Fluorescence was then induced with an excitation light of $750 \mathrm{mmol} \mathrm{m}^{-2} \mathrm{~s}^{-1}$ intensity. Fluorescence kinetics were monitored for the subsequent 20 seconds. The ratio of the variable fluorescence component $\left(F_{v}\right)$ to maximal fluorescence $\left(\mathrm{F}_{\mathrm{m}}\right)$, an indication of PSII efficiency, will be calculated.

The amounts of chlorophyll $a$ and $b$, and carotenoids were determined for foliage. Following determination of foliar surface area, pigments from foliar samples were extracted in $5 \mathrm{ml}$ of N,Ndimethylformamide (DMF) in the dark and at $4{ }^{\circ} \mathrm{C}$ for a period of 14 days. ${ }^{37}$ Following extraction, a 100 $\mathrm{mL}$ aliquot was diluted to $2 \mathrm{ml}$ in DMF and assayed to determine light absorbance at 440,644 , and 662 $\mathrm{nm}$ wavelengths using an ultraviolet/visible spectrophotometer (Hewlett Packard, Inc.). The concentration of the three pigments in the solution was calculated according to Wellburn and Lichtenthaler. $^{38}$

\section{Biochemical Measurements}

All enzymes were examined kinetically to determine $K_{M}$ and $V_{\max }$ which was utilized as a measure of response mechanism (up/down regulation or increased enzyme content). RuBCase and SPS enzyme concentration was assessed via Western blot analysis. Ribulose-1,5-bisphosphate carboxylase (RuBCase;E.C. 4.1.1.39) was extracted using established procedures. ${ }^{39}$ RuBCase activity was followed spectrophotometrically employing a Hewlett Packard Diode Array spectrophotometer equipped with a thermo-regulated cuvette holder. ${ }^{40}$ Sucrose phosphate synthase (SPS, E.C. 2.3 .1 .14 ) was extracted using established procedures ${ }^{41}$ with the following modification; SPS activity was measured spectrophotometrically using the continuous assay of Kerr et $\mathrm{al}^{42}$

\section{Experimental Design}

The study was conducted using a split-plot design. The three levels of atmospheric $\mathrm{CO}_{2}$ concentrations, the main plot factor, was randomly assigned to 18 open-top chambers to provide 6 replications. Within each chamber, 100 families of $P$. ponderosa $(80$ half-sibling families, 15 full-sibling families, and 5 openpollinated families) were grown (however, only 9 families were used in the study reported here). Thus family represented a sub-plot factor. All biochemical, gas exchange and light harvesting measurements were taken in July 1994, after 16 months of exposure.

\section{RESULTS}

\section{Growth}

Stem diameter differences in family growth measurements (Figure la) were statistically significant $(\mathrm{p} \leq 0.05)$. Additionally there was a trend of increased stem diameter growth with increased $\mathrm{CO}_{2}$ treatment. Height measurements tended to show a large increase at $+175 \mathrm{ppm} \mathrm{CO}_{2}$, while growth relative to ambient trees was minimal or negative at $+350 \mathrm{ppm} \mathrm{CO}_{2}$ (Figure 1b). Families 3087 and 3399 represented two of the better growth performers in relation to elevated $\mathrm{CO}_{2}$, while Family 3088 was the poorest growth performer.

\section{Photosynthesis}

All three families had a positive photosynthetic response to increasing $\mathrm{CO}_{2}$, where their photosynthetic rates increased with increasing levels of $\mathrm{CO}_{2}$ (Figure 2). The differences in photosynthesis were 
statistically significant $(\mathrm{p} \leq 0.05)$. Furthermore, there were no significant $\mathrm{CO}_{2} \times$ Family interactions, indicating that the photosynthetic response of the three families to increasing $\mathrm{CO}_{2}$ was not significantly different.

\section{Chlorophyll fluorescence}

Our chlorophyll fluorescence results showed a significant family specific response to the different $\mathrm{CO}_{2}$ treatments, as indicated by the relative efficiencies of photochemical transfer in photosystem II (Fv/Fm; Figure 3). Increasing $\mathrm{CO}_{2}$ resulted in a decrease in $\mathrm{Fv} / \mathrm{Fm}$ in all families. However, the decrease in Family 3088 was greater than the other two families. The range in percent change in Fv/Fm (comparing ambient to ambient +350 ) was $-3.2 \%,-5.0 \%$, and $-4.4 \%$ for Families 3087,3088 , and 3399 , respectively.

\section{Photosynthetic pigments}

The ANOVA showed significant reductions in chlorophyll $a$, chlorophyll $b$, and the carotenoids due to elevated $\mathrm{CO}_{2}$. The ANOVA also showed significant family effects on pigmentation. The July results showed a significant reduction in chlorophyll a due to elevated $\mathrm{CO}_{2}(13.1,11.8$, and 11.3 and $11.9 \mathrm{mg} \mathrm{m}^{-2}$ for ambient, ambient $+175 \mathrm{ppm} \mathrm{CO}_{2}$, and ambient $+350 \mathrm{ppm} \mathrm{CO}_{2}$ respectively). For chlorophyll $b$ these values were $4.1,4.1$, and $3.7 \mathrm{mg} \mathrm{m}^{-2}$ for ambient, ambient $+175 \mathrm{ppm} \mathrm{CO}_{2}$, and ambient $+350 \mathrm{ppm} \mathrm{CO}_{2}$, respectively. For carotenoids these values were $8.3,7.3$, and $7.3 \mathrm{mg} \mathrm{m}^{-2}$ for ambient, ambient $+175 \mathrm{ppm} \mathrm{CO}_{2}$, and ambient $+350 \mathrm{ppm} \mathrm{CO}_{2}$, respectively. There were also significant family interactions. In Tables 1, 2, and 3, Families 3087 and 3399 showed a more pronounced decreased in chlorophyll a, chlorophyll b, and carotenoids, than did Family 3088 . These differences are amplified by examining total chlorophyll content (Table 4). Comparing ambient to ambient $+350 \mathrm{ppm}$, the percent change in total chlorophyll content was $-27.6 \%,-5.0 \%$, and $-16.0 \%$ for Families 3087,3088 , and 3399 , respectively. The Chlorophyll $a / b$ ratio showed no significant differences between ambient and treatment groups.

\section{Biochemical Measurements}

Although there was an increase in photosynthesis with increasing $\mathrm{CO}_{2}$ for all families, this increase was not associated with RuBPCase activity (Figure 4). Results showed that there was a decrease in RuBPCase activity with increasing $\mathrm{CO}_{2}$ for all families. However, the results for SPSase were the opposite. For Families 3087 and 3399, there was an increase in SPS activity with increasing $\mathrm{CO}_{2}$, especially for Family 3399 at ambient +350 ppm (Figure 5). Family 3088 did not show this trend. SPS activity in Family 3088 increased at ambient $+175 \mathrm{ppm}$, but decreased at ambient $+350 \mathrm{ppm}$ (the activity at ambient $+350 . \mathrm{ppm}$ was less than the activity at ambient). SPS activity was the only measured parameter that significantly separates out the differences between the families, and correlates with growth performance.

\section{DISCUSSION}

The increased growth rate associated with elevated $\mathrm{CO}_{2}$ was observed in all nine families. However, the extent of intraspecific variability supports earlier findings from long-term studies. ${ }^{43,44}$ The increased growth might be explained by the fact that more carbon is readily available to the plants, which could be assimilated at a greater rate and utilized for new tissue growth. The differences in growth performance could be due to the poor growth performers not being as well adapted to handle the increase in atmospheric carbon availability. Poor growth performance in seedlings subjected elevated $\mathrm{CO}_{2}$ could be due to less efficient photosynthesis, thereby emitting more fluorescence. Although all families studied experienced a similar reduction in photosystem efficiency, with an increase in photosynthetic rates. Our observed increase in photosynthesis agrees with the general observation that elevated atmospheric $\mathrm{CO}_{2}$ 
enhances photosynthetic performance of $\mathrm{C} 3$ species. $^{45}$ A review of the literature indicated that observed increases in photosynthetic rates averaged near $40 \%$ for coniferous tree species and near $60 \%$ for deciduous tree species. ${ }^{21}$

With regard to photosynthetic pigments, we saw that the pigments of all trees were affected approximately equally by the elevated $\mathrm{CO}_{2}$ treatments. This may lead us to conclude that the pigment reduction may be partially responsible for the intraspecific reduction in photosystem II efficiency (Fv/Fm), possibly in conjunction with observed decreases in RuBPCase.

One possible explanation for the observed decreasing trends in Fv/Fm, pigmentation, and RuBPCase is that their reduction might not be a sign that the seedlings are stressed, but that an adaptive alteration in their physiology has occurred. ${ }^{17}$ For example, this would mean that the plants need to harvest less light for photosynthesis, and are actually functioning more efficiently. Apparently there is a reduction in light harvesting pigments, but even with a reduction in pigments, there still may be a surplus of light energy as indicated by a reduction in quantum efficiency (as indicated by Fv/Fm) but an increase in growth.

Furthermore, with regard to RuBPCase, the predominant effect of elevated $\mathrm{CO}_{2}$ on metabolic limitations to assimilation is to shift the balance between carboxylation and oxygenation activities of ribulose 1,5 bisphosphate carboxylase (RuBCase). With increased $\mathrm{CO}_{2}$ concentrations, carboxylation is favored over oxygenation. The effect on net photosynthesis is two-fold as increased carboxylation efficiency directly increases the rate of assimilation while a decrease in oxygenation activity results in decreased photorespiration. ${ }^{46}$ In our study, we would conclude that all three families have developed an adaptive response, with an increase in carboxylation efficiency which is indicated by an increase in net photosynthesis, but a decrease in RuPBCase activity (i.e. the plants need less enzymatic activity to acquire more carbon).

Of all the parameters measured, only SPSase activity showed distinct differences among the families. Specifically, Family 3088 showed a decrease in SPS activity at ambient $+350 \mathrm{ppm}$, as well as the poorest growth performance. SPSase represents the third control point in our conceptual framework, leading to long-term storage. Families 3087 and 3399 had significant increases in SPSase activity, enabling the export of sugars to long-term sinks (eg. growth). Family 3088 , with similar $\mathrm{CO}_{2}$ assimilation but the possibility of reduced export, could be experiencing $\mathrm{CO}_{2}$ induced stress. Betsche ${ }^{44}$ (1994) mentions several ways in which high concentrations of $\mathrm{CO}_{2}$ could cause stress to a plant: Oversized starch granules (which have been observed in trees from the present study), formed in response to elevated $\mathrm{CO}_{2}$ levels could hinder gas diffusion or cause physical membrane damage. High $\mathrm{CO}_{2}$ concentrations may induce low inorganic phosphate concentrations which can limit chloroplast ATP synthase. Alternatively the treatments could induce feedback-inhibition and eventual photosynthetic decline because of imbalance between $\mathrm{CO}_{2}$ fixation and assimilate utilization. It is possible that the seedlings of Family 3088 are being

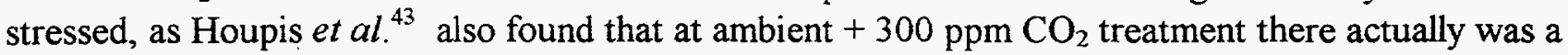
decrease in growth after 2 years of exposure. Perhaps as the present study continues, we will see a decrease in growth in certain families at the highest $\mathrm{CO}_{2}$ treatment

\section{CONCLUSIONS}

Carbon assimilation and accumulation represents several coordinating biochemical and physiological processes which are regulated but not overall limited by a series of self integrating source/sink feedback loops. By simultaneously studying various biochemical and physiological traits, and relating these to changes in growth of $P$. ponderosa due to elevated levels of atmospheric $\mathrm{CO}_{2}$, we have gained some insight into the long-term effects of this gas (which is rapidly accumulating in our environment) upon a 
dominant forest species. Through further work of this nature, and following these traits as well as others, through the course of multiple years and across seasons, we hope to be able to gain a greater understanding of plant physiology and biochemistry, while learning how atmospheric conditions affect forests.

\section{ACKNOWLEDGMENTS}

We would like to acknowledge Thorpe Loeffler, Roland $\mathrm{Ng}$, and Ramford $\mathrm{Ng}$ for their participation in the collection and analysis of the data. This research was performed under the auspices of the U.S. Department of Energy at Lawrence Livermore National Laboratory under contract W-7405-Eng-48.

\section{REFERENCES}

1. R. Allen, "The impact of $\mathrm{CO}_{2}$ on world climate," Environment, 22(10): 6-38 (1980).

2. T.M.L. Wigley, P.D. Jones, and P.M. Kelly, "Scenario for a warm, high- $\mathrm{CO}_{2}$ world," Nature, 283: 17-21 (1980).

3. J. Hansen, D. Johnson, A. Lacis, S. Lebedeff, P. Lee, D. Rind, and G. Russell, "Climatic impact of increasing atmospheric carbon dioxide," Science, 213 (28): 957-966 (1981).

4. W.S. Broecker, "Unpleasant surprises in the greenhouse?," Nature, 328:123-126 (1987).

5. G. Marland, The prospect of solving the $\mathrm{CO}_{2}$ problem through global reforestation, DOE/NBB-0082. Report to U.S. Dept. of Energy, Office of Energy Research, Washington D.C., 1988, 66pp.

6. R.A. Sedjo, "Forests: A tool to moderate global warming?," Environment, 31(1):15-20 (1989).

7. J. Pastor and W.M. Post, "Response of Northern forests to $\mathrm{CO}_{2}$-induced climate change," Nature, 334 : 55-58 (1988).

8. P.J. Kramer, "Carbon dioxide concentration, photosynthesis, and dry matter production," Bioscience, $31: 2933$ (1981).

9. D. Eamus and P.G. Jarvis, "The direct effects of increase in the global atmospheric $\mathrm{CO}_{2}$ concentration on natural and commercial temperate trees and forests," Adv. Ecol. Res., 19:1-55 (1989).

10. L.C. Tolley and B.R. Strain, "Effects of $\mathrm{CO}_{2}$ enrichment and water stress on growth of Liquidamber styriciflua and Pinus taeda seedlings," Can. J. Bot., 62:2135-2139 (1984).

11. D.Y. Hollinger, "Gas exchange and dry matter allocation responses to elevation of atmospheric $\mathrm{CO}_{2}$ concentration in seedlings of three tree species," Tree Physiol., 3:193-202 (1987).

12. H.H. Rogers, G.B. Reunion, and S.V. Krupa, "Plant response to atmospheric $\mathrm{CO}_{2}$ enrichment with emphasis on the rhizosphere," Environ. Poll., 83:155-189 (1994). 
13. P. Kramer and N. Sionit, "Effects of increasing $\mathrm{CO}_{2}$ concentration on the physiology and growth of forest tree," The Greenhouse Effect, Climate Change and U.S. Forests, W.E. Shands and J.S. Hoffman, Eds. The Conservation Foundation. Washington D.C., 1985, pp. 219-246.

14. N. Sionit, B.R. Strain, and H. Hellmers, "Long-term atmospheric $\mathrm{CO}_{2}$ enrichment affects the growth and development of Liquidambar styraciflua and Pinus taeda seedlings," Can. J. For. Res., 15:468-471 (1985).

15. K.A. Surano, P.F. Daley, J.L.J. Houpis, J.H. Shinn, J.A. Helms, R.J. Palassou and M.P. Costella, "Growth and physiological responses of Pinus ponderosa Dougl ex P. Laws. to long-term elevated $\mathrm{CO}_{2}$ concentrations," Tree Physiol., 2:243-259 (1986).

16. N. Fetcher, C.H. Jaeger, B.R. Strain, and N. Sionit, "Long-term elevation of atmospheric $\mathrm{CO}_{2}$ concentration and the carbon exchange rates of saplings of Pimus taeda $\mathrm{L}$. and Liquidambar styaciflua L.," Tree Physiol, 4:255-262 (1988).

17. J.L.J. Houpis, K.A. Surano, S. Cowles, and J.H. Shinn, "Chlorophyll and carotenoid content of two varieties of Pinus ponderosa seedlings subjected to long-term elevated carbon dioxide," Tree Physiol., 4:187-193 (1988).

18. J.P. Conroy, P.J. Milham, M. Mazur, and E.W.R. Barlow, "Growth, dry weight partitioning and wood properties of Pinus radiata D. Don after 2 years of $\mathrm{CO}_{2}$ enrichment," Plant, Cell, and Environ., 13:329-337 (1990).

19. B. Acock and L.H. Allen, "Crop responses to elevated carbon dioxide concentration," Direct effects of increasing carbon dioxide on vegetation, B. Strain and J. Cure Eds. U.S. Department of Energy, Washington D.C., 1985, pp 53-97.

20. J.L.J. Houpis, D.Anschel, J.C. Pushnik, P.D. Anderson and R.S. Demaree, "Seasonal and intraspecific variability of chlorophyll fluorescence, pigmentation and growth of Pinus ponderosa subjected to elevated $\mathrm{CO}_{2}$," Can. J. For. Res., Submitted (1995).

21. R. Ceulmans and M. Mousseau, "Effects of elevated atmospheric $\mathrm{CO}_{2}$ on woody plants," New Phytol., 127:425-446 (1994).

22. S.M. Assmann, "Stomatal and non-stomatal limitations to carbon assimilation: an evaluation of the path-dependent method," Plant, Cell and Environment, 11:577-582 (1988).

23. K.R. Brown, "Carbon dioxide enrichment accelerates the decline in nutrient status and relative growth rate of Populus tremuloides Michx. seedlings," Tree Physiol., 8:161-173 (1991).

24. S. Yelle, R.C. Beeson,Jr., M.J. Trudel, and A. Gosselin, “Acclimation of two tomato species to high $\mathrm{CO}_{2}$," Plant Physiol., 90:1465-1472 (1989)

25. W. Spenser and G. Bowes, "Photosynthesis and growth of water hyacinth under $\mathrm{CO}_{2}$ enrichment," Plant Physiol., 82:528-533 (1986). 
26. U.D. Havelka, R.C. Ackerson, M.G. Boyle, and V.A. Wittenbach, " $\mathrm{CO}_{2}$ enrichment effect on soybean physiology. I. Effects of long-term $\mathrm{CO}_{2}$ exposure," Crop Sci., 24:1146-1150 (1984).

27. L.J. Samuelson and J.R.Sieler, "Interactive role of elevated $\mathrm{CO}_{2}$, nutrient limitations, water stress in the growth response of red spruce seedlings," Forest Sci., 39:348-358 (1992).

28. W.J. Arp, "Effects of source-sink relations on photosynthetic acclimation to elevated $\mathrm{CO}_{2}$," Plant, Cell Environ., 14:869-875 (1991).

29. H.K. Lichtenthaler, "The Kautsky effect: 60 years of chlorophyll fluorescence induction kinetics," Photosynthetica, 27:45-54 (1992).

30. H.K. Lichtenthaler and U. Rinderle, "The role of chlorophyll fluorescence in the detection of stress conditions in plants," CRC Critical Reviews in Anal. Chem., 19:S29-S85 (1988).

31. G.H. Krause and E.Weis, "Chlorophyll fluorescence: the basics," Annual Review of Plant Physiol., 42:313-349 (1991).

32. J.L.J. Houpis, K.A. Surano, S. Cowles, and J.H. Shinn, "Chlorophyll and carotenoid content of two varieties of Pinus ponderosa seedlings subjected to long-term elevated carbon dioxide," Tree Physiol., 4:187-193 (1988).

33. P.S. Nobel, Physiological and Environmental Plant Physiology, Academic Press, Inc., New York, 1991, 635pp.

34. S.C. Huber and J.L. Huber, "Role of sucrose-phosphate synthase in sucrose metabolism in leaves," Plant Physiol., 99:1275-1278 (1992).

35. R.B. Thomas and B.R. Strain, "Root restriction as a factor in photosynthetic acclimation of cotton seedlings grown in elevated carbon dioxide," Plant Physiol., 96:627-634 (1991).

36. S.P. Long and B.G. Drake, "Effect of long-term elevation of $\mathrm{CO}_{2}$ concentration in the field on the quantum yield of photosynthesis of the $C_{3}$ sedge, Scirpus olneyi," Plant Physiol., 96:221-226 (1992).

37. R. Moran and D. Porath, "Chlorophyll determination in intact tissues using N,N dimethylformamide," Plant Phyisol., 65:478-479 (1980).

38. A.R. Wellburn and H.K. Lichtenthaler, "Determinations of total cartenoids and chlorophylls a and b of leaf extracts in different solvents," in Abstracts of the 6th International Congress on Photosysnthesis, Brussels, Belgium, 1983, pp. 415.

39. D.T. Tissue, R.B. Thomas, and B.R. Strain, "Long-term effects of elevated $\mathrm{CO}_{2}$ and nutrients on photosynthesis and rubisco in loblolly pine seedlings," Plant Cell Environ., 16:859-865 (1993).

40. J. Van Oosten, D. Afif, and P. Dizengremel, "Long-term effect of a $\mathrm{CO}_{2}$ enriched atmosphere on enzymes of the primary carbon metabolism of spruce trees," Plant Physiology and Biochemistry, 30:541547 (1992). 
41. W. Kalt-Torres, P.S. Kerr, and S.C. Huber, "Isolation and characterization of multiple forms of maize leaf sucrose-phosphate synthase," Physiol. Plant., 70:653-658 (1987).

42. P.S. Kerr, W. Kalt-Torres, and S.C. Huber, "Resolution of two multiple forms of sucrose-phosphate synthase from maize, soybean and spinach leaves," Planta, 170:515-519 (1987).

43. J.L.J. Houpis, K.A. Surano, P.F. Daley, and J.H. Shinn, "Growth and morphology of Pinus ponderosa seedlings fumigated for two years with elevated $\mathrm{CO}_{2}$," in Proceedings of the Ninth North American Forest Biology Workshop on Physiological and Genetic Basis of Forest Decline, Stillwater, Oklahoma, 1986, pp.19-26.

44. T. Betsche, "Atmospheric $\mathrm{CO}_{2}$ enrichment: kinetics of chlorophyll a fluorescence and photosynthetic $\mathrm{CO}_{2}$ uptake in individuals, attached cotton leaves," Environ. Exp. Botany, 34:75-86 (1994).

45. G. Bowes, "Facing the inevitable: plants and increasing atmospheric $\mathrm{CO}_{2}$," Annu. Rev. Plant Physiol. Plant Mol. Biol., 44:309-332 (1993).

46. J. Conroy and $\mathrm{P}$. Hocking, "Nitrogen nutrition of $\mathrm{C} 3$ plants at elevated atmospheric $\mathrm{CO}_{2}$," Physiol. Plant. 89:570-576 (1993). 
Table 1. Chlorophyll a content $\left(\mu \mathrm{g} \mathrm{cm}^{-2}\right)$.

\begin{tabular}{c|ccc}
\hline Family & Ambient & Ambient $+175 \mathrm{ppm}$ & Ambient +350 ppm \\
\hline 3087 & $12.12 \pm 0.86$ & $10.19 \pm 0.87$ & $8.72 \pm 0.85$ \\
3088 & $11.91 \pm 1.00$ & $12.03 \pm 0.78$ & $11.14 \pm 0.93$ \\
3399 & $13.36 \pm 1.15$ & $12.81 \pm 0.67$ & $11.25 \pm 0.78$ \\
\hline
\end{tabular}

Table 2. Chlorophyll b content $\left(\mu \mathrm{g} \mathrm{cm}^{-2}\right)$.

\begin{tabular}{c|ccc}
\hline Family & Ambient & Ambient $+175 \mathrm{ppm}$ & Ambient $+350 \mathrm{ppm}$ \\
\hline 3087 & $3.72 \pm 0.49$ & $3.07 \pm 0.41$ & $2.76 \pm 0.33$ \\
3088 & $3.63 \pm 0.50$ & $3.85 \pm 0.35$ & $3.63 \pm 0.48$ \\
3399 & $4.11 \pm 0.47$ & $3.94 \pm 0.32$ & $3.41 \pm 0.41$ \\
\hline
\end{tabular}

Table 3. Carotenoid content $\left(\mu \mathrm{g} \mathrm{cm}^{-2}\right)$

\begin{tabular}{c|ccc}
\hline Family & Ambient & Ambient $+175 \mathrm{ppm}$ & Ambient $+350 \mathrm{ppm}$ \\
\hline 3087 & $7.58 \pm 0.53$ & $6.76 \pm 0.51$ & $5.72 \pm 0.51$ \\
3088 & $7.55 \pm 0.59$ & $7.63 \pm 0.50$ & $7.01 \pm 0.52$ \\
3399 & $8.31 \pm 0.69$ & $7.97 \pm 0.37$ & $7.18 \pm 0.43$ \\
\hline
\end{tabular}

Table 4. Total chlorophyll content $\left(\mu \mathrm{g} \mathrm{cm}^{-2}\right)$. Numbers in parentheses are the percent change in total chlorophyll from ambient.

\begin{tabular}{c|ccc}
\hline Family & Ambient & Ambient +175 ppm & Ambient +350 ppm \\
\hline 3087 & $15.84 \pm 1.34$ & $13.25 \pm 1.26(-16.4 \%)$ & $11.47 \pm 1.15(-27.6 \%)$ \\
3088 & $15.53 \pm 1.47$ & $15.88 \pm 1.11(2.3 \%)$ & $14.76 \pm 1.41(-5.0 \%)$ \\
3399 & $17.47 \pm 1.59$ & $16.75 \pm 0.97(-4.1 \%)$ & $14.67 \pm 1.17(-16.0 \%)$ \\
\hline
\end{tabular}


$\mathrm{CO}_{2}$ Level

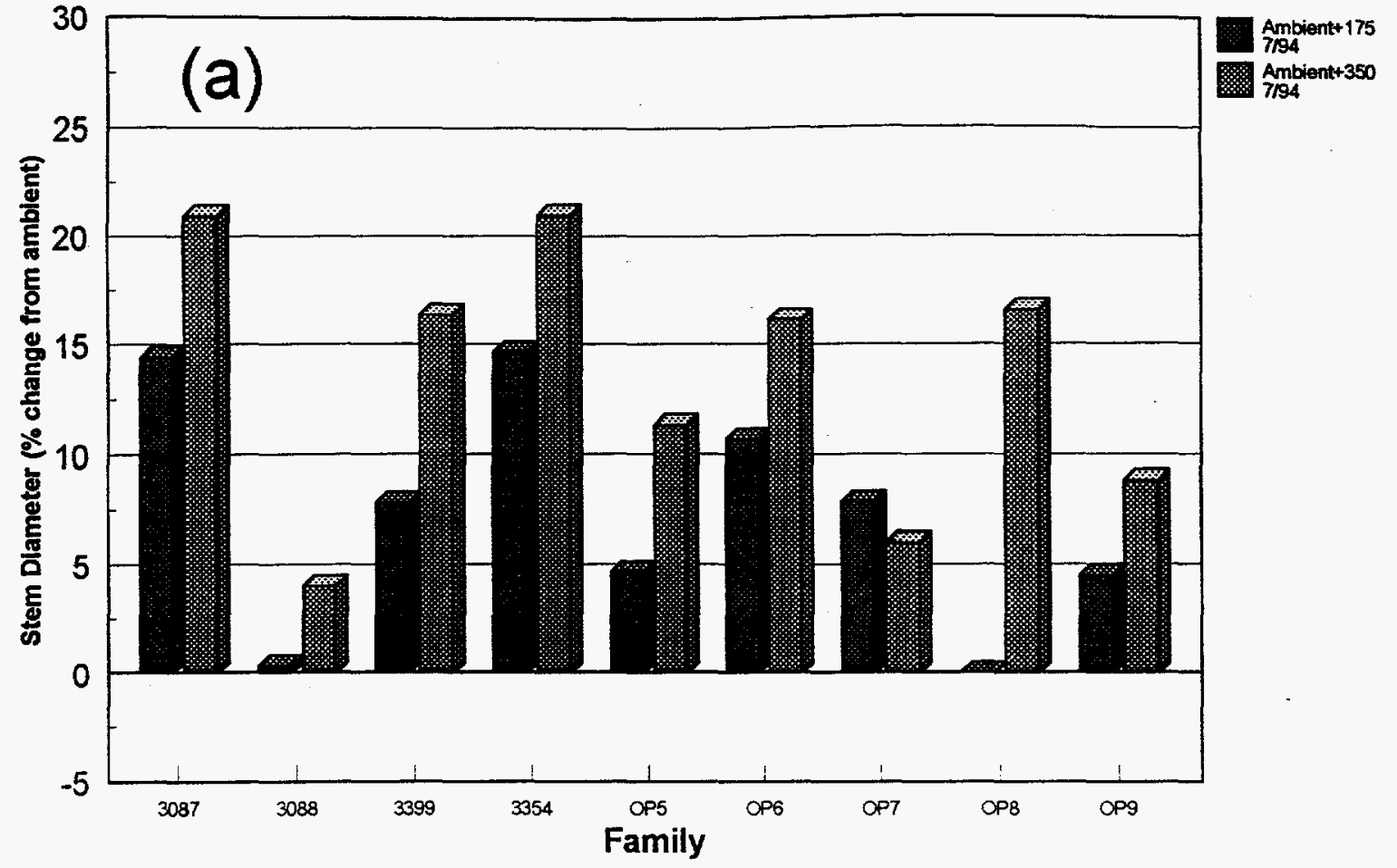

$\mathrm{CO}_{2}$ Level

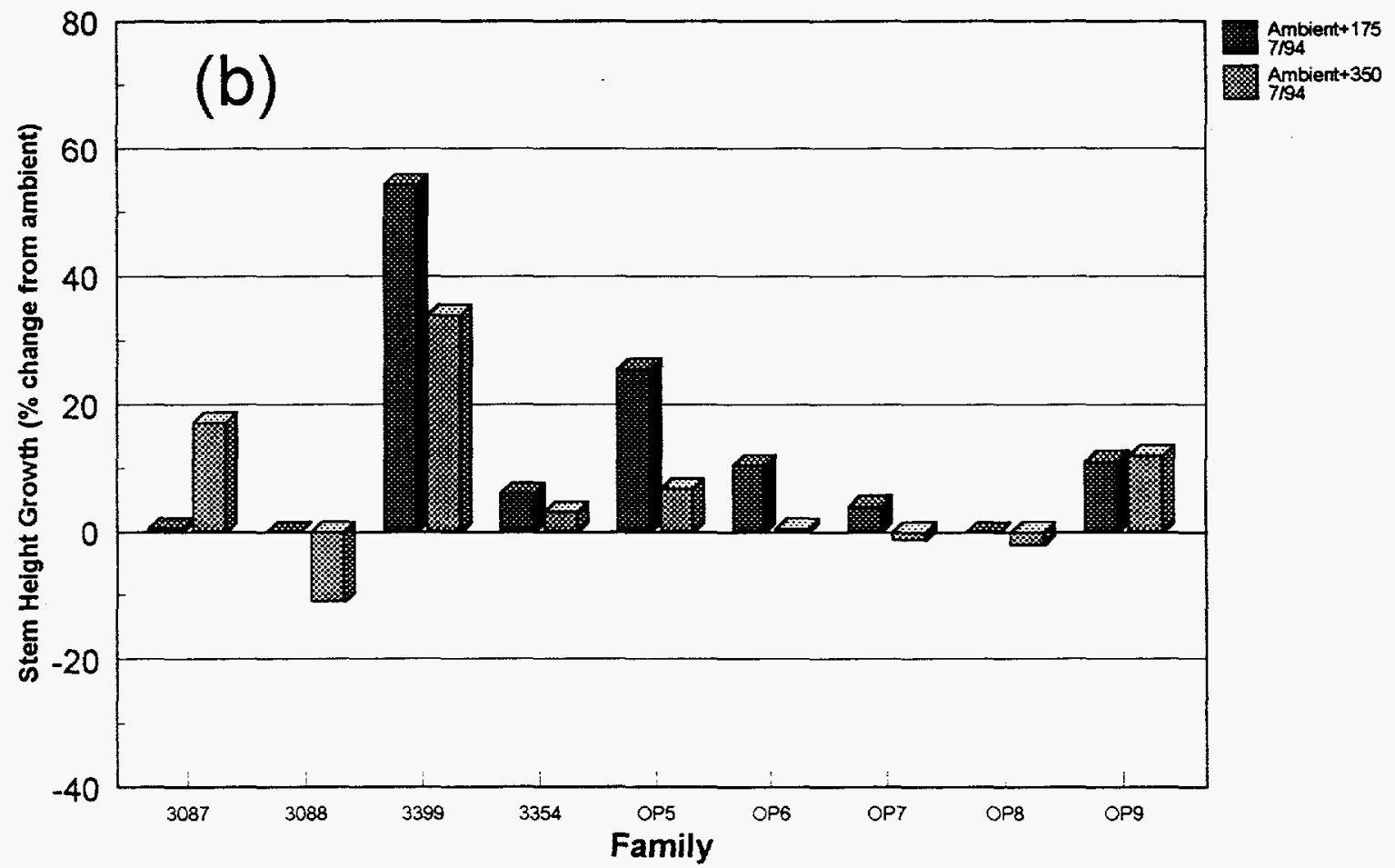

Figure 1. Stem diameter growth (a) and stem height growth (b) for nine families of Pinus ponderosa after 16 months of continuous exposure to elevated $\mathrm{CO}_{2}$ (values are expressed as a percent change from ambient). 


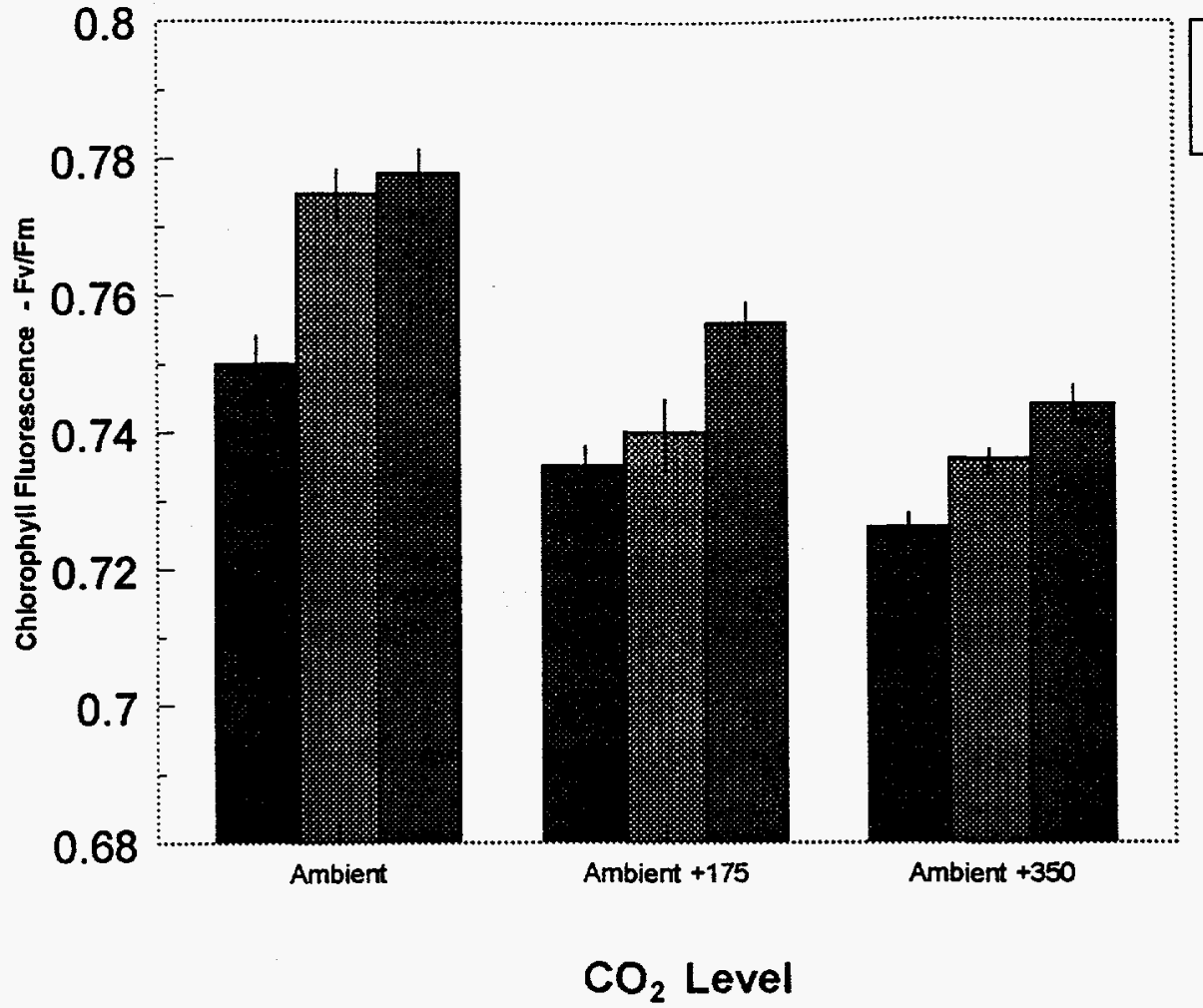

Figure 2. Chlorophyll fluorescence (Fv/Fm ratio) for 3 half-sibling families of $P$. ponderosa seedlings subjected to one of three levels of $\mathrm{CO}_{2}$ for 16 months.

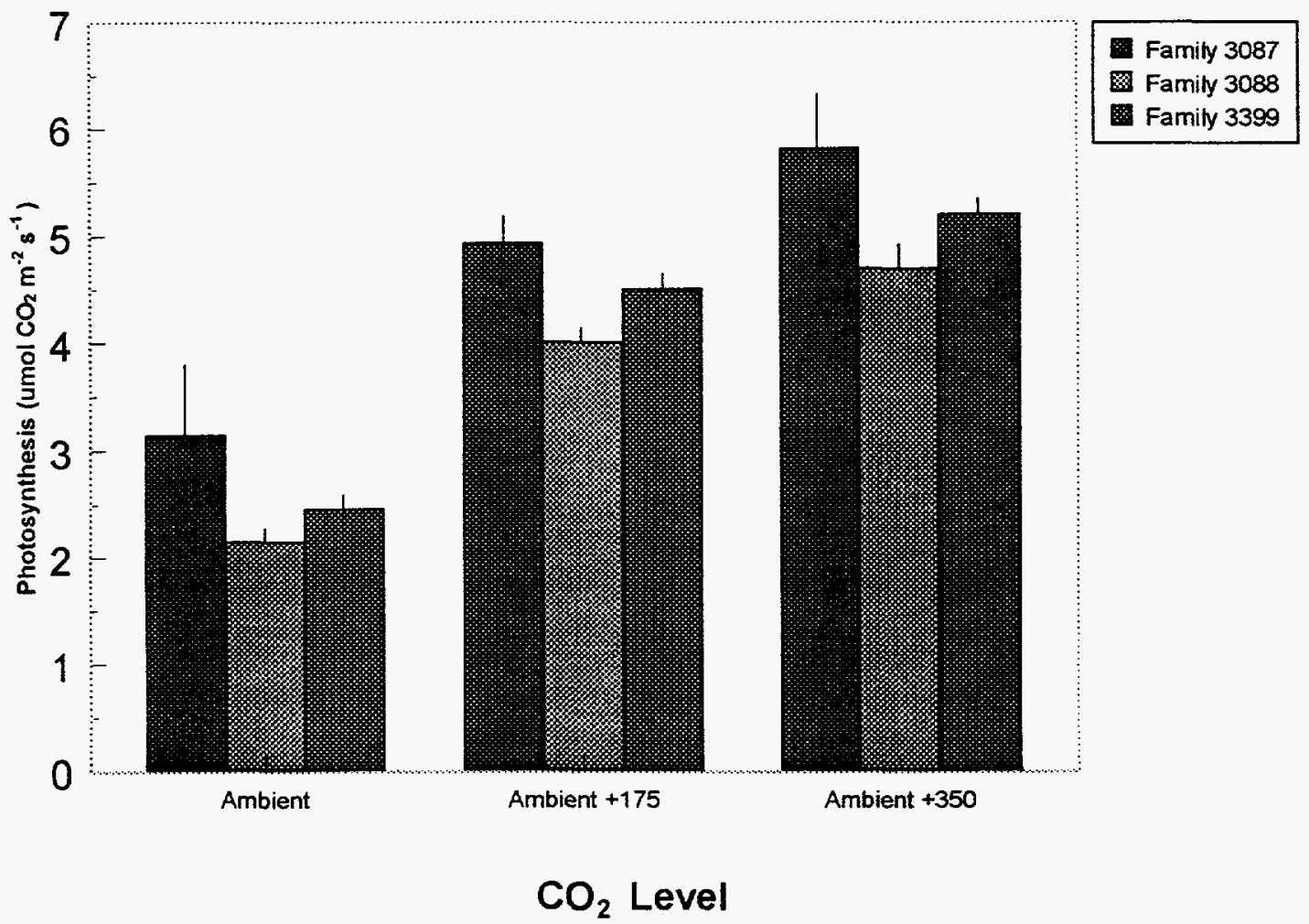

Figure 3. Photosynthesis for 3 half-sibling families of $P$. ponderosa seedlings subjected to one of three levels of $\mathrm{CO}_{2}$ for 16 months 


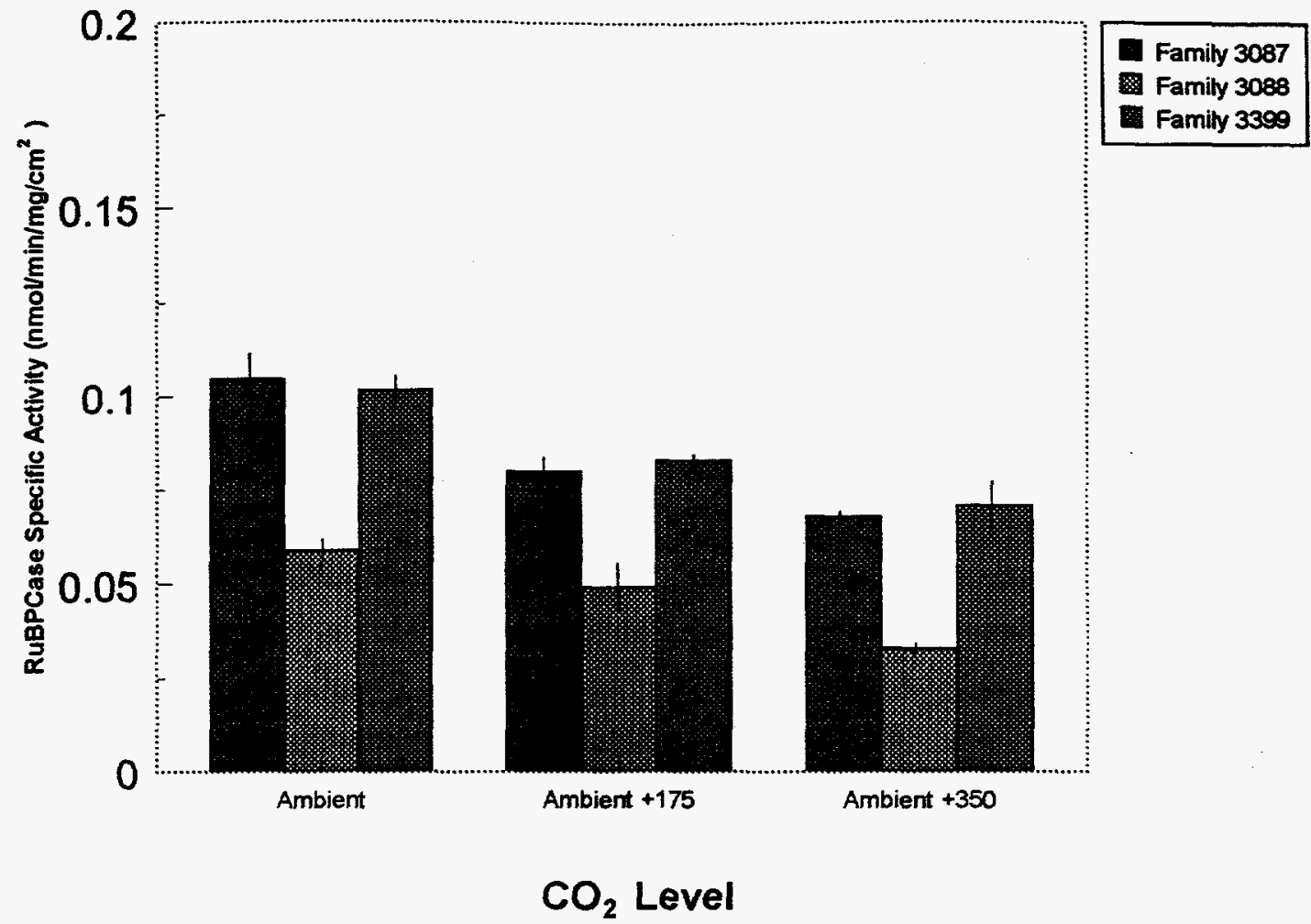

Figure 4. RuBPCase activity for 3 half-sibling families of $P$. ponderosa seedlings subjected to one of three levels of $\mathrm{CO}_{2}$ for 16 months.

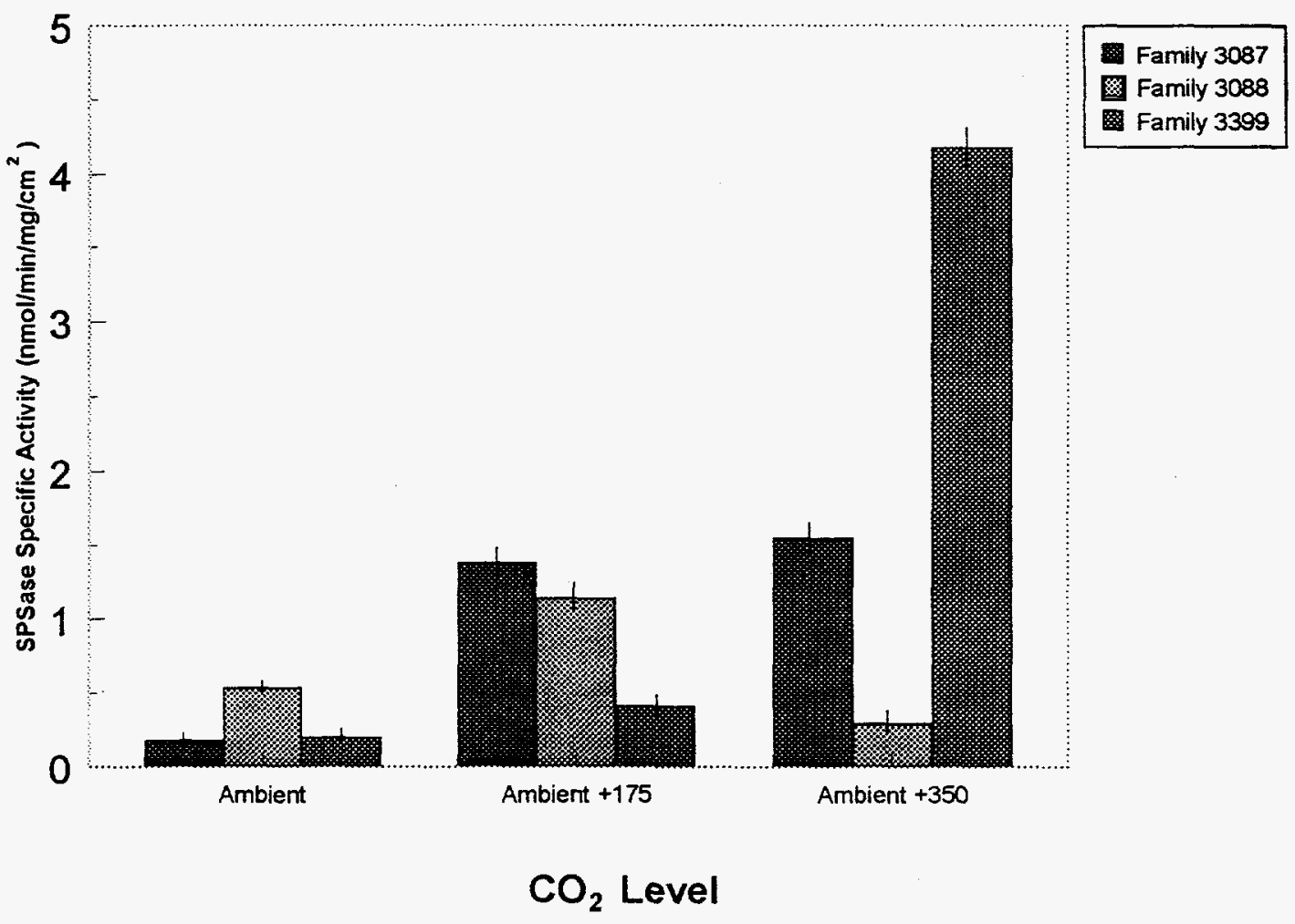

Figure 5. SPSase activity for 3 half-sibling families of $P$. ponderosa seedlings subjected to one of three levels of $\mathrm{CO}_{2}$ for 16 months. 